\title{
EMPLOYEES MOTIVATION AND TRANSITION OF ISO 9001 QMS TOWARDS TQM
}

\author{
Marija Stannojevska \\ Zito Polog AD, Macedonia \\ Robert Minovski \\ Faculty of Mechanical Engineering, University of Cyril and Methodius, Macedonia \\ Bojan Jovanoski \\ Faculty of Mechanical Engineering, University of Cyril and Methodius, Macedonia \\ Zvonko Sajfert \\ University of Novi Sad, Technical faculty "Mihajlo Pupin”, Serbia \\ Dragan Ćoćkalo \\ University of Novi Sad, Technical faculty “Mihajlo Pupin”, Serbia \\ Sanja Stanisavljev \\ University of Novi Sad, Technical faculty "Mihajlo Pupin”, Serbia
}

Employees' motivation enables improvement in the effectiveness of the implementation process of Total Quality Management (TQM). Orientation towards process and their control, without significant emphasis of the employees, generates problems with the team work and communication, failure to meet or delaying of deadlines, increasing the total costs etc. Employee motivation means incentive for their complete and dedicated inclusion in the operation that contributes towards improved quality implementation of the TQM practices in a shorter period of time. Although aforementioned aspects are treated in the literature, still, the influence of the employees motivation on the transition from ISO 9001 QMS towards TQM is almost not covered at all. In that direction, the main objective of the paper is to create a generalized conceptual model for considered transition. For that sake, identification of the influential factors of ISO 9001, TQM and employees motivation as well as their analysis and determination of the most influential factors is carried out. The final set of factors is used as initial set of variables for creation of generalized conceptual model. The model introduces the correlation dependencies between the variables of treated areas. The created conceptual model in the advanced research will serve as a basis for design of a dynamic SD model which will enable experimentation in direction of transition of ISO 9001 towards TQM practices depending on the motivation of employees.

Keywords:TQM, ISO 9001, transition, employees motivation.

\section{INTRODUCTION}

In the contemporary dynamic environment, the traditional business organizations are not capable of coping with the challenges of the modern corporate operations. Advanced managerial concepts emerged in many world-class companies as mechanisms for reaching the objectives. One of them is the Total Quality Management (TQM). Oakland [01] defines TQM as an approach for market sustainability of the organizations which improves the efficiency, flexibility and the working competitiveness, and for which meeting the clients' requirements represents a major objective [01]. The TQM implementation enables the organizations the ability for rapid adaptation to the changes in the environment, which enables TQM organizations to become competitive on the global market. Quality management systems like the ISO 9001standard in many organisations represent additional stimulation for further TQM development. The ISO 9001 standard became commonly accepted in the management of the organizations. Indeed, with the ISO 9001standard, organisations demonstrate quality and confidence while meeting the expected requirements of the clients. Adequate preconditions are needed for introduction of advanced managerial concepts. Employee motivation is one of them. Inclusion of employees gives them an opportu- 
nity to improve their personal abilities, to gain appropriate knowledge, to increase their confidence, to express the individual creativity and to participate in solving specific problems. The opportunity to participate represents an inspiration for active engagement of the employees, thus generating drastic quality approach change in their performance.TQM philosophy represents an integral part of the creation of a climate in which employees are encouraged to locate the quality problems and find a solution for them.

\section{CONNECTION BETWEEN TQM, ISO 9001 AND EMPLOYEE MOTIVATION}

Numerous studies in the last period are oriented towards determination of the connection between the ISO 9000 series and the human resources management in the context of quality management [02]. Papers that are of concern are found by searching the literature available at EBSCO and Scopus. Key words of the research are the following: connection, TQM, ISO 9000, employees motivation. The paper of the author Martinez-Costa investigates the connection between the TQM and the ISO 9000 series, their reflection on the performance and implementation motive, however, it does not treat the level of effective operation of ISO 9001 as a basis for transition to TQM [03]. In the paper of Brown et al. it was concluded that the motive for certification of the ISO 9000 series stimulates the introduction of the TQM concept [04]. Thus, the role of the top management whose responsibility is to provide adequate training for the employees for transition from the ISO 9000 series towards the TQM is emphasized. The paper of Sila and Ebrahimpour claims that the top management plays a crucial role in the successful implementation of the TQM within the organizations [05]. A similar view is confirmed in the paper of Fotopoulos et al., which states that the role of the top management in the application of the TQM practices in the performance is significant [06]. However, the inclusion of employees is not treated. According to Pool, the implementation of the TQM principles in organisations with developed organisational culture is proportionally dependent on the organizational learning, which enables successful start in introducing advanced methodologies [07]. The view of Rice is that "only the employees can improve the process, and just only if they are motivated" [08]. Tang et al. highlights that TQM practices increase loyalty of the employees, which leads towards increasing of their level of satisfaction [09]. Chen, represents similar views in his study [10]. The continuous improvement within the organisations is enabled through introduction of mechanisms for motivation of the employees, according to Swartling [11].

In the reviewed papers the assumption suggests that the introduction of ISO 9001 is a precondition for transition into TQM and the motivation of the employees has a positive impact on the successful implementation of TQM. This brief literature overview brings several conclusions. The successful operation of ISO 9001 is a precondition for integration of TQM practices in the organization. The role of the employees as operation carriers can be of significant importance in the process of transition from ISO 9001 to TQM within the organizations. Therefore, inclusion of employees should be continuously encouraged and strengthened. Motivation is the mechanism that can increase the involvement and dedication of the employees in the process of transition from ISO 9001 to TQM. Still, no papers with structuralized generalized conceptual model of the transition from ISO 9001 towards TQM depending on the motivation of the employees, have been found.

\section{RESEARCH METODOLOGY}

In order to identify influential factors, analysis of the literature in the field of TQM, ISO 9001 and employee motivation has been conducted. Upon identification of numerous key factors, a selection of the most influential factors has been made and the connection between them has been studied. In the following step, the conceptual model for the transition from ISO 9001 towards the TQM depending on the motivation of the employees has been created.

\section{IDENTIFICATION OF THE INFLUENTIAL FACTORS IN THE AREA OFTQM, ISO 9001 AND EMPLOYEE MOTIVATION}

After the conducted comprehensive research of the literature based upon Emerald, Scopus and EBSCO, in the period from August 2012 to February, 2015, a total of 25 papers in the area of TQM, published in English, have been found, according following key words: TQM, elements, influential factors and critical factors, used during the research. Eight TQM influential factors, whose importance is confirmed by various authors, have been identified (Table 1). 
Table 1.TQM influential factors

\begin{tabular}{|c|c|}
\hline $\begin{array}{l}\text { TQM } \\
\text { influential } \\
\text { factors }\end{array}$ & Literary source \\
\hline $\begin{array}{l}\text { Strong com- } \\
\text { mitment of top } \\
\text { management }\end{array}$ & $\begin{array}{l}\text { Soltani [12], Talib et al. [13], Kanji } \\
\text { [14], Saraph et al. [15], Flynn et al. } \\
\text { [17], Anderson et al. [18], Chase } \\
\text { [18], Yasamis et al. [19], Black et } \\
\text { al. [20], Koh et al. [21], Burati et al. } \\
\text { [22] Spasojevic-Brkic et al. [23]. }\end{array}$ \\
\hline $\begin{array}{l}\text { Customer } \\
\text { focus }\end{array}$ & $\begin{array}{l}\text { Oakland [1], Flynn et al. [17], Ahire } \\
\text { et al. [24], Chase [18], Yasamis et } \\
\text { al. [19], Black et al. [20], Koh et al. } \\
\text { [21]. }\end{array}$ \\
\hline $\begin{array}{l}\text { Employee } \\
\text { involvement }\end{array}$ & $\begin{array}{l}\text { Rice [9], Chang [25], Chen [10], } \\
\text { Psychogios et al. [26], Dubey } \\
\text { [27], Swartling et al. [11], Pool [7], } \\
\text { Saraph et al. [15], Ahire et al. [24], } \\
\text { Chase [18], Yasamis et al. [19], } \\
\text { Black et al. [20], Koh et al. [21], } \\
\text { Burati et al. [22]. }\end{array}$ \\
\hline $\begin{array}{l}\text { Supplier } \\
\text { management }\end{array}$ & $\begin{array}{l}\text { Zhang et al. [28], Saraph et al. [15], } \\
\text { Flynn et al. [17], Ahire et al. [24], } \\
\text { Chase [18], Yasamis et al. [19], } \\
\text { Black et al. [20], Koh et al. [21], } \\
\text { Burati et al. [22]. }\end{array}$ \\
\hline $\begin{array}{l}\text { Quality } \\
\text { information } \\
\text { management }\end{array}$ & $\begin{array}{l}\text { Flynn et al. [17], Saraph et al. [15], } \\
\text { Ahire et al. [24], Yasamis et al. [19], } \\
\text { Black et al. [20], Koh et al. [21], } \\
\text { Burati et al. [22]. }\end{array}$ \\
\hline $\begin{array}{l}\text { Process } \\
\text { management }\end{array}$ & $\begin{array}{l}\text { Mardani et al. [29], Yasamis et al. } \\
\text { [19], Black et al. [20], Koh et al. } \\
\text { [21], Chase [18]. }\end{array}$ \\
\hline $\begin{array}{l}\text { Organizational } \\
\text { learning }\end{array}$ & $\begin{array}{l}\text { Senge [30], Edmondson et al. [31], } \\
\text { Andersson [32], Barson et al. [33], } \\
\text { McLaughlin et al. [34], Spasojevic- } \\
\text { Brkic et al. [35], Sila et al. [36], } \\
\text { Black et al. [20]. } \\
\end{array}$ \\
\hline $\begin{array}{l}\text { Continuous } \\
\text { improvement }\end{array}$ & $\begin{array}{l}\text { Das et al. [37], Pheng et al. [38], } \\
\text { Juran et al. [39], Anderson et al. } \\
\text { [18], Crosby (1979), Chase [18], } \\
\text { Yasamis et al. [18], Black et al. [20] } \\
\text { Koh et al. [21], Burati et al. [22]. }\end{array}$ \\
\hline
\end{tabular}

TQM concept is based on quality management principles of ISO 9000 series of standards, which are stimulation for further implementation of TQM. The eight quality management principles of ISO 9000 series are:

1) Customer focus

2) Leadership
3) Involvement of people

4) Process approach

5) System approach to management

6) Continuous improvement

7) Factual approach to decision-making

8) Mutually beneficial supplier relationships

The influential factors in ISO 9001 are listed in the requirements of the quality system i.e. they are included in the items of the standard and re referring to Table 2.

Table 2.ISO 9001 influential factors

\begin{tabular}{|l|c|}
\hline \multicolumn{1}{|c|}{ ISO 9001 influential factors } & Point \\
\hline $\begin{array}{l}\text { Responsibility, authority and } \\
\text { communication }\end{array}$ & 5.5 \\
\hline Planning & 5.4 \\
\hline Management review & 5.6 \\
\hline Resource management & 6.1 \\
\hline Human resources & 6.2 \\
\hline Infrastructure & 6.3 \\
\hline Work environment & 6.4 \\
\hline Planning of product realization & 7.1 \\
\hline Customer - related processes & 7.2 \\
\hline Design and development & 7.3 \\
\hline Purchasing & 7.4 \\
\hline Production and service provision & 7.5 \\
\hline Monitoring and measurement & 8.2 \\
\hline Conform of nonconforming product & 8.3 \\
\hline Analysis of data & 8.4 \\
\hline $\begin{array}{l}\text { Measurement, analysis and } \\
\text { improvement }\end{array}$ & 8.5 \\
\hline
\end{tabular}

If employees are familiar with the benefits of TQM, their motivation to participate in the TQM implementation is on a higher level. Research of the literature based upon EBSCO and Scopus, in the period from July, 2014 to February, 2015 has been conducted in order to identify the influential factors in the area of motivation of employees. A total of 29 papers published in English have been found, according to key words: motivation, involvement, satisfaction and employees. It has been determined that the authors are oriented towards researching the effects of the different factors that affect the motivation of the employees and are represented in Table 3. 
Table 3.Employees motivation influential factors

\begin{tabular}{|c|c|}
\hline $\begin{array}{l}\text { Influence factor of } \\
\text { employee } \\
\text { motivation }\end{array}$ & Literary source \\
\hline Training & $\begin{array}{c}\text { Chapman [40], Daily [41], } \\
\text { Hynes [42], Miller [43], } \\
\text { Spasojevic-Brkic et al. } \\
\text { [23]. }\end{array}$ \\
\hline Teamwork & $\begin{array}{c}\text { Osterloh [44], Daily [41], } \\
\text { Pietrese [45], Spasojevic- } \\
\text { Brkic et al. [23]. }\end{array}$ \\
\hline Empowerment & $\begin{array}{c}\text { Manzoor [46], Baldoni } \\
\text { [47], Hill [48]. }\end{array}$ \\
\hline Rewarding & $\begin{array}{c}\text { Aselstine [49], Bonnie } \\
\text { [50], Rice [9]. }\end{array}$ \\
\hline $\begin{array}{l}\text { Working Environ- } \\
\text { ment }\end{array}$ & $\begin{array}{l}\text { Korzinsky [51], } \\
\text { Jajaweera [52]. }\end{array}$ \\
\hline Recognition & Manzoor [46], Milne [53]. \\
\hline Encouragement & Milne [53]. \\
\hline Respect & Maslow [54]. \\
\hline Well-being & $\begin{array}{l}\text { Luo [55], Sheperd [56], } \\
\text { Rice [9]. }\end{array}$ \\
\hline Trust & Manzoor [46], Jafri [57]. \\
\hline $\begin{array}{c}\text { Autonomy and skill } \\
\text { variety }\end{array}$ & $\begin{array}{l}\text { Hackman et al. [58], Sul- } \\
\text { tan [59], Osterman [60]. }\end{array}$ \\
\hline Job satisfaction & $\begin{array}{c}\text { Chen et al. [10], Elias } \\
\text { [61], Sultan [59], Christ } \\
\text { [62], Yperen [63], Chang } \\
\text { [25]. }\end{array}$ \\
\hline
\end{tabular}

\section{CONCEPTUAL MODEL OFTRANSITION}

The identified influential factors in the area of TQM, ISO 9001 and the motivation of employees are used for the creation of the conceptual model presented in Figure 1. It can be noticed that the model is too complicated and up to a level of non-functionality. Therefore, a process for simplification of the model has been initiated, which means, assumption of the most critical influential factors and deciding which factors can be simplified due to their low-level impact on the treated area or because some of the factors are part of previously identified features. Factors with status "critical" are listed in the List of included factors (Table 4). All remaining factors that have a certain influence on the treated areas and which can be simplified in accordance with chosen criteria are part of the List for simplification (Table 5).

The conceptual model constructed only by the critical factors is presented in Figure 2:

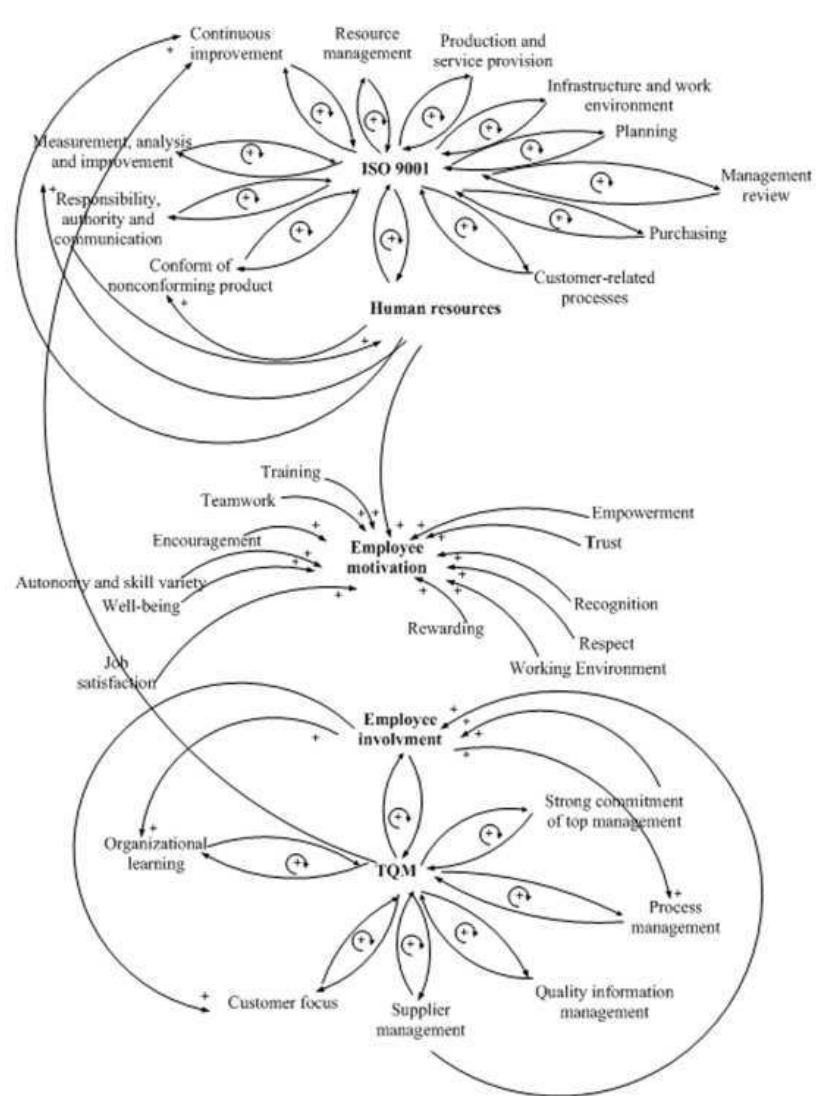

Figure 1: Conceptual model of transition from ISO 9001 towards TQM depending on the motivation of employee by all influential factors

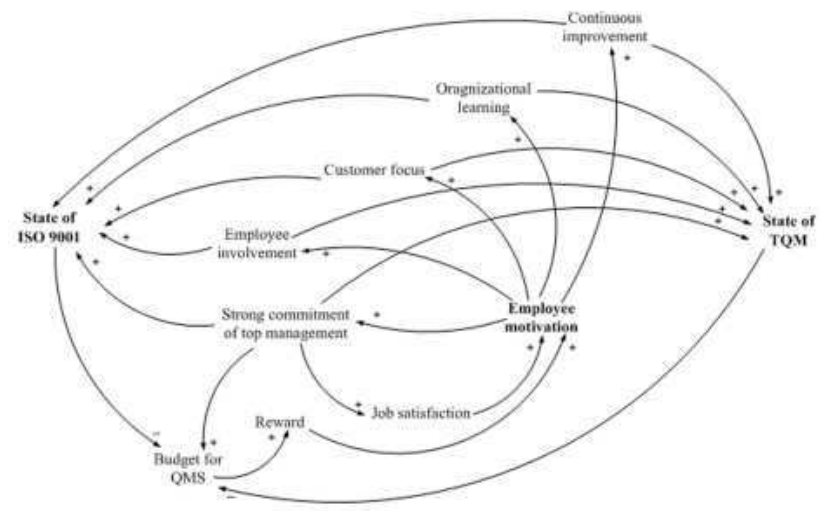

Figure 2: Conceptual model of transition from ISO 9001 towards TQM depending on the motivation of employee by critical factors

The validation of the model of transition from ISO 9001 towards TQM under the influence of the motivation of employees is made based upon the existing studies with quantified correlation dependencies between most of the specific variables (Table 6).

\section{DISCUSSION}

Numerous influential factors have been identified in the study. The simplification enables a kind of filtration of the essential factors that have 
strongest influence on the treated problem out of all identified influential factors. In doing so, the study becomes oriented and strongly focused. A total of eight influential factors have been identified in the area of TQM, out of which, five have been identified as critical and the remaining three factors have been evaluated as factors with an impact on the successful implementation of TQM. However, they are not of significant importance for the motivation of employees. Sixtheen influential factors have been identified in the area of ISO 9001. Nevertheless, each one of them represents an integral part of some of the
TQM factors in accordance with the eight principles of quality management in the ISO 9000 series. Eleven factors that lead towards increase of the motivation have been identified in the area of motivation of employees. Only two factors (rewarding and work satisfaction) that can impact the increase of motivation in a short period of time have been separated due to their similar nature.

The positive mutual influences of the critical factors in the area of TQM, ISO 9001 and motivation of employees are presented in the conceptual model.

Table 4. List of factors

\begin{tabular}{|c|c|}
\hline $\begin{array}{l}\text { TQM critical } \\
\text { factor }\end{array}$ & Description of TQM critical factor \\
\hline $\begin{array}{l}\text { Strong com- } \\
\text { mitment of top } \\
\text { management }\end{array}$ & $\begin{array}{l}\text { According to Kanji [14], the commitment of top management is a key driver for TQM imple- } \\
\text { mentation and successful business. The employee's motivation of is very addictive with top } \\
\text { management. }\end{array}$ \\
\hline $\begin{array}{l}\text { Customer fo- } \\
\text { cus }\end{array}$ & $\begin{array}{l}\text { Customer focus is expressed as the production of goods that fulfill the customer's need. } \\
\text { Market research is essential because it is not easy to meet customer expectations [1]. Or- } \\
\text { ganizations have to express customer's concerns and respond to the customer demands } \\
\text { and to measure their satisfaction [28]. Collecting the information about customer needs is } \\
\text { one of the TQM practices to improve the business performance [58]. Customer focus is } \\
\text { closely related with employees motivation because employees are customers at the same } \\
\text { time. }\end{array}$ \\
\hline $\begin{array}{l}\text { Organizational } \\
\text { learning }\end{array}$ & $\begin{array}{l}\text { Organizational learning covers skill for creating, acquiring and transferring knowledge to } \\
\text { employees, and ability to create the new knowledge [64]. Organizational learning is posi- } \\
\text { tively correlated with TQM concept [65], enables successful TQM implementation [7] and } \\
\text { significantly affect to the employee motivation. }\end{array}$ \\
\hline $\begin{array}{l}\text { Continuous im- } \\
\text { provement }\end{array}$ & $\begin{array}{l}\text { The factor of continuous improvement means evaluation of the processes performance and } \\
\text { collection of all data related to the quality [37]. According to TQM concept, quality is the } \\
\text { measurable category. The effect of the improvement means measurement of the initial and } \\
\text { the expected level [38]. The process of the employee motivation to participate in the imple- } \\
\text { mentation of TQM practicies is a dynamic process, with the point of beginning, but without } \\
\text { the point of end. The only way to keep the level of customer satisfaction is the continuous } \\
\text { improvement [13]. According to Swartling [11], motivation affect to the continuous improve- } \\
\text { ment. The employees are treated as a customers, because they are internal customers. }\end{array}$ \\
\hline $\begin{array}{l}\text { Employee in- } \\
\text { volvment }\end{array}$ & $\begin{array}{l}\text { Involvement of the employees allows usage of the entire capacity of the employees and } \\
\text { encourage their commitment to organizational success [66]. Part of the TQM philosophy is } \\
\text { motivating employees to locate problems in terms of quality and find a solution for them. } \\
\text { The integral part of TQM philosophy is the motivation of the employee to identify the prob- } \\
\text { lems related to quality. Motivating employees lead to higher quality, better productivity and } \\
\text { increase the competitiveness of the market organizations [41]. }\end{array}$ \\
\hline Rewarding & $\begin{array}{l}\text { The system of rewarding should be tailored to the needs of the organization according to } \\
\text { the achievements of the employees. }\end{array}$ \\
\hline $\begin{array}{l}\text { Job satisfac- } \\
\text { tion }\end{array}$ & $\begin{array}{l}\text { Job satisfaction leads to better organizational performance and have a significant impact } \\
\text { on employee motivation [10]. }\end{array}$ \\
\hline
\end{tabular}


Table 5. List of simplification

\begin{tabular}{|c|c|c|}
\hline Influence factor & Description of the influence factor & Reason for simplification \\
\hline $\begin{array}{l}\text { Process } \\
\text { management }\end{array}$ & $\begin{array}{l}\text { The production process should be organized to en- } \\
\text { sure the defined quality products and prevention of } \\
\text { nonconformities, so the quality should be built into } \\
\text { the process. Quality product can be produced in } \\
\text { the quality process. }\end{array}$ & $\begin{array}{l}\text { Top management is responsible for } \\
\text { the process approach and therefore, } \\
\text { this factor will not significantly affect } \\
\text { to the motivation of employees. }\end{array}$ \\
\hline $\begin{array}{l}\text { Quality } \\
\text { information } \\
\text { management }\end{array}$ & $\begin{array}{l}\text { Access to data is very important in terms of sharing } \\
\text { the information and knowledge between employ- } \\
\text { ees or customers and it is one of the preconditions } \\
\text { for the implementation of TQM [21]. }\end{array}$ & $\begin{array}{l}\text { Quality information management in- } \\
\text { crease the motivation of employees, } \\
\text { but it not be treated in the simplified } \\
\text { model, because the impact on mo- } \\
\text { tivation is not so high, compared to } \\
\text { other TQM included factors listed in } \\
\text { Table 4. }\end{array}$ \\
\hline $\begin{array}{l}\text { Supplier } \\
\text { management }\end{array}$ & $\begin{array}{l}\text { TQM philosophy supports the principle of long term } \\
\text { relationships with suppliers [28]. }\end{array}$ & $\begin{array}{l}\text { The supplier management have an } \\
\text { influence on the TQM implementa- } \\
\text { tion, but it have not major impact on } \\
\text { the employee motivation. }\end{array}$ \\
\hline $\begin{array}{l}\text { Responsibility, } \\
\text { authority and } \\
\text { communication }\end{array}$ & $\begin{array}{l}\text { ISO } 90001: 2008(5.4) \\
\text { Top management have a fully involvement in the } \\
\text { quality management system. They have to make } \\
\text { sure that the requirements of the management } \\
\text { system are integrated into the organization's pro- } \\
\text { cesses and that the policy and objectives are com- } \\
\text { patible with the } \\
\text { strategic direction of the organization }\end{array}$ & $\begin{array}{l}\text { It will be treated within the factor } \\
\text { strong commitment of top manage- } \\
\text { ment. }\end{array}$ \\
\hline Purchasing & $\begin{array}{l}\text { ISO } 90001: 2008 \text { (7.4) } \\
\text { The organization shall ensure that purchased prod- } \\
\text { uct conforms to specified purchase requirements. } \\
\text { The type and extent of control applied to the sup- } \\
\text { plier and the purchased product shall be dependent } \\
\text { upon the effect of the purchased product on subse- } \\
\text { quent product realization or the final product. }\end{array}$ & $\begin{array}{l}\text { It will be treated within the factor } \\
\text { supplier management. }\end{array}$ \\
\hline Training & $\begin{array}{l}\text { The training enables strengthening of teamwork } \\
\text { and involvement of employees in TQM implementa- } \\
\text { tion [40]. According to Daily [41], the training of em- } \\
\text { ployees, indirectly by the teamwork, have a positive } \\
\text { impact on reinforcing the employee involvement. }\end{array}$ & $\begin{array}{l}\text { It will be treated within the factor em- } \\
\text { ployee involvement. }\end{array}$ \\
\hline Teamwork & $\begin{array}{l}\text { Team working, is a kind of tool for expansion of } \\
\text { the knowledge base. Team working increase the } \\
\text { individual contributions of employees and provides } \\
\text { solving of the organizational issues. According to } \\
\text { Daily [41], teamwork is positively correlated with } \\
\text { successful employee involvement in TQM imple- } \\
\text { mentation. }\end{array}$ & $\begin{array}{l}\text { It will be treated within the factor em- } \\
\text { ployee involvement. }\end{array}$ \\
\hline Well-being & $\begin{array}{l}\text { Emotional decline of the employee+s have impact } \\
\text { of the work performance and leads to achieving } \\
\text { poor result [55]. }\end{array}$ & $\begin{array}{l}\text { Well-being is closely related to job } \\
\text { satisfaction factor, because the wel- } \\
\text { fare of employees arise from their } \\
\text { satisfaction due remuneration. Well- } \\
\text { being will be treated within the factor } \\
\text { rewarding. }\end{array}$ \\
\hline
\end{tabular}


Table 6. Validation of correlations in the conceptual model

\begin{tabular}{|c|c|c|c|}
\hline \multicolumn{2}{|c|}{ Correlation between variables } & Author & Factor analysis value \\
\hline \multirow{3}{*}{$\begin{array}{l}\text { Substantial commitment } \\
\text { of top } \\
\text { management }\end{array}$} & State of ISO 9001 & Kimutal et al. [67] & $\begin{array}{l}>0,5 \text { (significant correla- } \\
\text { tion), confirmed by } 76 \% \text { of } \\
\text { interviewed organizations }\end{array}$ \\
\hline & State of TQM & Das et al. [37] & $\begin{array}{l}>0,815(>0,50 \text { significant } \\
\text { correlation) }\end{array}$ \\
\hline & Employee motivation & Mezher [68] & $0,551(0-1)$ \\
\hline \multirow{3}{*}{ Organizational learning } & State of ISO 9001 & Tamayo-Torres [69] & $\begin{array}{l}0,57(>0,50 \text { significant cor- } \\
\text { relation) }\end{array}$ \\
\hline & State of TQM & Das et al. [37] & $\begin{array}{l}>0,850(>0,50 \text { significant } \\
\text { correlation })\end{array}$ \\
\hline & Employee motivation & Malik et al. [70] & $\begin{array}{l}0,68(>0,5 \text { significant cor- } \\
\text { relation) }\end{array}$ \\
\hline \multirow{3}{*}{ Customer focus } & State of ISO 9001 & Piskar [71] & $\begin{array}{l}0,69(>0,5 \text { significant cor- } \\
\text { relation) }\end{array}$ \\
\hline & State of TQM & Das et al. [37] & $\begin{array}{l}>0,838(>0,50 \text { significant } \\
\text { correlation })\end{array}$ \\
\hline & Employee motivation & Ugboro et al. [73] & $\begin{array}{l}0,5103(>0,50 \text { significant } \\
\text { correlation) }\end{array}$ \\
\hline \begin{tabular}{|l} 
Continuous \\
improvement
\end{tabular} & State of TQM & Das et al. [37] & $\begin{array}{l}>0,830(>0,50 \text { significant } \\
\text { correlation })\end{array}$ \\
\hline \multirow[b]{2}{*}{ Employee involvement } & State of ISO 9001 & Respati [73] & $\begin{array}{l}>0,828(>0,50 \text { significant } \\
\text { correlation })\end{array}$ \\
\hline & State of TQM & Das et al. [37] & $\begin{array}{l}0,77(>0,50 \text { significant } \\
\text { correlation) addict between } \\
\text { behavior and ISO } 9000\end{array}$ \\
\hline \multirow[b]{2}{*}{ Employee motivation } & Reward & Das et al. [37] & $\begin{array}{l}>0,844(>0,50 \text { significant } \\
\text { correlation })\end{array}$ \\
\hline & Job satisfaction & $\begin{array}{l}\text { Kappelman et } \\
\text { al. [74] }\end{array}$ & $\begin{array}{l}0.343 \\
1(>0,9 \text { significant correla- } \\
\text { tion ) chi square method }\end{array}$ \\
\hline
\end{tabular}

It is obvious that the inclusion of the employees shall increase if their motivation is on a higher level. On the other hand, the motivation of the employees will increase through rewards and work satisfaction. The rewarding depends on available budget for the system of quality management, which positively affects to the state of the ISO 9001 and TQM. Based on the positive correlation it is very clear that the increase of the motivation will lead towards higher level of inclusion of employees, higher dedication of the top management, strengthening the focus on the clients, intensifying the organizational learning that leads towards continuous improvement of the quality management system, and generally improvement of the organizational performance.
The states of TQM and ISO 9001 are negatively correlated with the budget for QMS, because the higher investment in QMS, cause budget cuts. The validation of the model is made in accordance with literary sources. Thus, for most of the mutual connection between the variables certain correlation dependencies studied from different authors have been found.

\section{CONCLUSION}

From the created conceptual model one can conclude that the inclusion of the employees is one of the critical factors for successful implementation of the TQM, and the motivation of the employees represents a sort of "initiator" that encourages their involvement and dedication to 
the work. The top management is responsible for identification and provision of the necessary resources for successful operation of ISO 9001 and transition towards TQM. Employees from other hierarchical levels are also implementers of decisions adopted by the top management, enforcers of defined principles and objectives of the highest level to the other organisational levels and direct participants and carriers of the operations. If the employees are not motivated enough, their participation in the improvement of ISO 9001 will be only formal and will not lead to further development of the system for quality and integration of the TQM practices in the process. Poor motivation of the employees may cause inertia and resistance to change leading to introduction of new methodologies such as the TQM. For those reasons, the creation of the conceptual model of the influence of the level of motivation of the employees who can, with their inclusion, influence the transition of the organizations from ISO 9001 towards TQM, is of significant importance. In the next study, this model will serve as a basis for designing a dynamic model for transition of the organisations from ISO 9001 towards TQM, under the influence of the motivation of employees.

\section{REFERENCE}

1) Oakland, J.S. (1995):Total quality management: Text with cases, Butterworth-Heinemann, London, U.K.

2) Spasojević-Brkić V. (2009):Contingency theory andquality management - Kontingentna teorija i menadzment kvalitetom (in Serbian), University of Belgrade, Faculty of Mechanical engineering.

3) Martinez-Costa, M. (2008): Simultaneous Consideration of TQM and series ISO 9000 on Performance and Motivation: An Empirical Study of Spanish Companies, International Journal of Production Economics, Vol. 113, No 1, pp. 23-39.

4) Brown, A., Wiele, T. (1996): A Tipology of Approaches to ISO Certification and TQM, Australian Journal of Management, Vol. 21, No. 1.

5) Sila, I., Ebrahimpour, M. (2003): Examination and comparison of the critical factors of total quality management (TQM) across countries, International Journal of Quality \& Reliability Management, Vol. 41, No. 2, pp. 235-268.

6) Fotopoulos, C.V., Evangelos, L. (2010): Investigating total quality management prac- tice's inter-relationships in ISO 9001:2000 certified organizations, Total Quality Management, Vol. 21, No. 5, $503-515$.

7) Pool, S.W. (2000): The learning organization: motivating employees by integrating TQM philosophy in a supportive organizational culture, Leadership \& Organization Development Journal, Vol. 21, No. 8, pp. 373-378..

8) Rice, W.R. (1993): Motivation: The MostBasic Process in TQM/CQI, JHG ,Vol.15, No 3.

9) Tang, Z., Wu, Z. (2010): Using behavior theory to investigate individual-level determinants of employee involvement in TQM, Total Quality Management, Bussiness Excellence, Vol. 21, No. 12, pp. 1231-1260.

10) Chen, C.C. (2009): Measuring Job Satisfaction How do managers know that after gaining an understanding of the theories of motivation and applying different approaches to increase job satisfaction that their efforts have been successful?, Management and Policy, Vol. 28.

11)Swartling, D., Poksinska, B. (2013): Management Initiation of continuous improvement from a Motivational perspective, Journal of Applied Economics and Business research, Vol. 3, No. 2, pp. 81-94.

12)Soltani, E., Lai, P., Gharneh, N. (2005): Breaking Through Barriers to TQMEffectiveness: Lack of Commitmentof Upper-Level Management, Total Quality Management, Vol. 16, No. 8-9, pp. 1009-1021.

13) Talib F., Rahman Z., Qureshi M.N. (2010): The relationship between total quality management and quality performance in the service industry: a theoretical model, International Journal of Business, Mangement and Social Sciences, Vol. 1, No.1, pp. 113-128.

14)Kanji, G.K. (1998): Measure of business excellence, Total Quality Management \& Business Excellence, Vol.9, No. 7, pp. 633-644.

15)Saraph, J.V., Benson, P.G., Schroeder, R.G. (1998): An instrument for measuring the critical factors of quality management, Decis. Sci., Vol. 20, No. 4, pp. 810-829.

16)Flynn, B.B., Schroeder, R.G., Sakakibara S. (1994): A framework for quality management research and an associated measurement instrument, J. Oper. Manage., Vol. 11, No. 4, pp. 339-366.

17)Andersson, L.. (2011): Barriers to organizational learning: A case study of a change project, The Institute of Economic Research, 
School of Economics and Management, Lund University, Conference for Organizational Learning, Knowledge and Capabilities, Hull.

18)Chase G.W. (1993): Effective total quality management (TQM) process for construction, J. Manage. Eng., Vol. 9, No. 4, pp. 433-443.

19) Yasamis, F., Arditi, D., Mohammadi, J. (2002): Assessing contractor quality performance, Constr. Manage. Econom., Vol. 20, No. 3, pp. 211-223.

20)Black, S.A., Porter, L..J. (1996): Identification of the critical factors of TQM, Decis. Sci., Vol. 27, No. 1, pp. 1-21.

21)Koh, T.Y., Low, S.P. (2010): Empiricist Framework for TQM Implementation in Construction Companies., Journal of management in engineering, Vol. 133.

22)Burati, J.L., Matthews, M.F., Kalidindi, S.N. (1992): Quality management organizations and techniques, J. Constr. Eng. Manage., Vol. 118, No. 1, pp. 112-128.

23)Spasojevic-Brkic V., Djurdjevic T., Sedmak T. (2012): Quality tools application in Serbian industrial enterprises, International Journal "Advanced Quality", Vol. 40, No. 2., pp. 37-40.

24)Ahire, S.L., Golhar, D.Y., Waller, M.A.. (1996): Development and validation of TQM implementation constructs, Decis. Sci., Vol 27, No. 1, pp. 23-56.

25)Chang, C.C., Chiu, C.M., Chen C.A. (2010): The effect of TQM practices on employee satisfaction and loyalty in government, Total Quality Management Vol. 21, No. 12, pp. 1299-1314.

26)Psychogios, A.G, Wilkinson, A., Szamosia, L.T. (2009): Getting to the heart of the debate: TQM and middle manager autonomy, Total Quality Management \& Business Excellence, Vol. 20, No. 4.

27)Dubey, S.K., Bansal, S. (2012): Barriers in implementing radical/incremental changes in manufacturing - based government organizations, Australian Journal of Business and Management Research, Vol. 2, No. 2 pp. 48-59.

28)Zhang, Z.H. (2000): Implementation of Total Quality Management: An Empirical Study of Chinese Manufacturing Firms, PhD thesis, University of Gronigen, Gronigen, The Nederlands.

29) Mardani, A., Kazemilari, M. (2012): Relationship between national culture and TQM implementation, Case study: Iranian multinational electrical manufacturing companies, Asian Journal of Management Research, Vol. 3, No. 1.
30)Senge, P.M. (1990): The Fifth Discipline. The Art and Practice of Learning Organization, New York, Doubleday/currency, pp. 101-113.

31) Edmondson, A., Moingeon, B. (1999): Learning trust and organizational change, Sage, London, pp. 157-175.

32)Anderson, J.C., Rungtusanathan, M., Schroeder, R.G. (1994): A theory of quality management underlying the Deming management method, Acad. Manage. Rev., Vol. 19, No. 3, pp. 472-509.

33)Barson, R., Foster, G., Struck, T., Ratchev, S., Pawar, K., Weber, F. and Wunram, M. (2000): Inter- and intra-organizational barriers to sharing knowledge in the extended supply chain. Conference Proceedings., University of Nottingham, Nottingham, 2000.

34)McLaughlin, S., Paton, R.A., Macbeth, D.K. (2008).: Barrier impact on organizational learning within complex organizations, Journal of Knowledge Management, Vol. 12, No. 2, pp.107-123.

35)Spasojević-Brkić V., Klarin M.M., Brkić A., Lučanin Dj.V.J., Milanović D.D. (2011): Simultaneous consideration of contingency factors and quality management: An empirical study of Serbian companies, Afr. J. Bus. Manage., Vol. 5 No. 3, pp: 866-883, 2011.

36) Sila, I., Ebrahimpour, M. (2002): An investigation of the total quality management survey based research published between 1989 and 2000, International Journal of Quality \& Reliability Management, No. 19, pp. 902-970.

37)Das, A., Paul, H., Sweirczek, F.W. (2008): Developing and validating total quality management (TQM) constructs in the context of Thailand's manufacturing industry, Benchmarking: An International Journal, Vol. 15, No. 1, pp. 52-72.

38)Pheng, L.S., Teo, J.A. (2004): Implementing Total Quality Mangement in Construction Firms, Jornal of management in engineering, Vol .8, No. 1, pp. 8-15.

39) Juran, J.M. (1995): A History of Manging for Quality, ASQC Quality Press, Milwaukee, MI.

40)Chapman, R.I.,Clarke, P., Sloan T. (1991): TQM in continuous-process manufacturing: Dow-Corning (Australia) Pvt. Ltd, International Journal of Quality and Management, Vol. 8, No. 5, pp. 77-90.

41)Daily, B.F. (2003): TQM Workforce factors and employee involvement: The pivotal role of teamwork, Journal of managerial issues, 
Vol. 15, No. 4, pp. 393-412.

42)Hynes, G.E. (2012): Improving Employees' Interpersonal Communication Competencies A Qualitative Study, Business and Professional Communication Quarterly, Vol. 75, No 4, pp. 466-475.

43)Miller, M. (2006): Developing an effective mentoring program, CMA MANAGEMENT, Vol. 80, No. 1, 2006.

44) Osterloh, M., Frost, J., Frey, B.S. (2002): The Dynamics of Motivation in New Organizational Forms, International Journal of the Economicsof Business, Vol. 9, No. 1, pp. 61-77.

45)Pieterse, A.N. (2013): Cultural diversity and team performance: The role of team member goal orientation, Academy of Management Journal, 2013, Vol. 56, No. 3, pp. 782-804.

46)Manzoor, Q. (2011): Impact of Employees Motivation on Organizational Effectiveness, European Journal of Business and Management, Vol. 3, No.3, pp. 36-44.

47)Baldoni, J. (2005): Great Motivation Secrets of Great Leaders, McGraw Hill.

48)Hill, F., Huq, R. (2004): Employee Empowerment: Conceptualizations, Aims and Outcomes, Total Quality Management, Total Quality Management \& Business Excellence, Vol. 15, No. 8, pp. 1025-1041.

49)Aselstine, K., Alletson, K. (2006): A new deal for the 21st century workplace, Ivey Business Journal, Vol. 4, No. 1.

50)Bonnie, G.M. (2002): Performance Appraisal Systems, Productivity and Motivation: A Case study, Public personal Management, Vol. 31, No. 2.

51)Korzynski, P. (2013): Employee motivation in new working environment, International Journal of Academic Research, Vol. 5, No. 5, pp. 184-188.

52) Jayaweera, T. (2015): Impact of Work Environmental Factors on Job Performance, Madiating Role of Work Motivation: A Study of Hotel Sector in England, International Journal of Business and Management, Vol. 10, No. 3.

53) Milne, P. (2007): Motivation, incentives and organisational culture, Journal of Knowledge Management, Vol. 11 No. 6, pp. $28-38$.

54)Maslow, A.H. (1954): Motivation and personality, New York: Harper \& Row.

55) Luo, L.. (1999): Work motivation, Job Stress and Employees'Well-being, Journal of Applied Management Studies, Vol. 8, No. 1.

56) Shepherd, D.A., Haynie, M., Patzelt, H. (2013): Project Failures Arising from Cor- porate Entrepreneurship: Impact of Multiple Project Failures on Employees' Accumulated Emotions, Learning, and Motivation, Journal of Production and Innovative Management, Vol. 30, No. 5, pp. 880-895.

57) Jafri, M.H. (2012): Impact of Employee Trust on Organizational Commitment and Innovative Behaviour of Employees: An Empirical Study on Public Sector Employees in Bhutan, Parokalpana: KIIT Journal of Management, pp. 11-26, 2012.

58)Hackman, J.R., Oldham, G.R. (1976): Motivation through the design of work: Test of theory. Organizational Behavior and Human Performance, Vol. 16, pp. 250-279.

59)Sultan S. (2012): Examining the Job Characteristics: A Matter of Employees' Work Motivation and Job Satisfaction, Journal of Behavioral Sciences, Vol. 22, No. 2, 2012.

60) Osterman, P. (2001): Supervision, Discretion and Work Organization, Motivation and Monitoring, Vol. 24, No. 2.

61)Elias, M., Smith, W., Barney, C.E.. (2012): Age as a moderator of attitude towards technology in the workplace: work motivation And overall job satisfaction, Behavior \& Information Technology, Vol. 31, No. 5.

62) Christ, M.H., Emett, S.A., Summers, S. L., Wood, D.A. (2012): The Effects of Preventive and Detective Controls on Employee Performance and Motivation, Contemporary Accounting Research, Vol. 29, No. 2, pp. 432-452.

63) Yperen, N.W.V.: Employees facing high job demands: How to keep them fit, satisfied, and instrinsically motivated? Academy of Management Proceedings August 2002 (meeting Apstract Supplement) B1-B6.

64) Senge, P. (1996): The Ecology of Leadership, Leader to leader, No. 2, pp.18-23, 1996.

65) Hafeez, K.. (2010): TQM, Innovation, Organisational Learning and Knowledge Economy: Is There a Connection?, 4th Quality Conference in the Middle East Proceedings, Dubai, UAE.

66) Cotton, J.L.. (1993): Employee Involvement, Newbuurry Park, NJ: Sage Pulications Inc.

67) Kimutal, G., Gachunga, H., Wanjau, K., Gichuhi, A. W. (2013): Influence of employee capacity on health workforce performance in Kenya's public health sector: A tale of ISO 9001:2008 certified hospitals, European Journal of Business and Social Sciences, 
Vol. 2, No.9, pp. 134-152.

68)Mezher, T., Ajam, M., Shehab, M. (2004): The historical impact of ISO 9000 on Lebanese firms, Quality Assurance, Vol. 1, No. 1, pp. 25-42.

69) Tamayo-Torres, J. (2014): Gutierrez-Gutierezz, L.J., Ruiz Moreno, J.: The relationship between exploration and exploitation strategies, manufacturing flexibility and organizational learning: An empirical comparison between non-ISO and ISO certified firma, European Journal of Operational Research, Vol 232, No. 1, pp. 72-86.

70)Malik, M.E., Danish, R.Q. (2010): Impact of Motivation to Learn and Job Attitudes on Organizational Learning Culture in a Public Service Organization of Pakistan, A Research Journal of South Asian Studies, Vol. 25, No. 2, pp. 217-235.

71)Piskar, F. (2007): The impact of the quality management system ISO 9000 on customer satisfaction of Slovenian companies, Managing Global Transitions, Vol. 5, No. 1, pp. 45-61.

72) Ugboro, I.O., Obeng, K. (2000): Top management leadership, employee empowerment, job satisfaction and customer satisfaction in TQM organizations: an empirical study, Journal of quality management, Vol. 5, pp. 247-272.
73)Respati, H., Amin R.. (2014): Research on Continues Mediation: Employee Behaviour and TQM Practice as ISO 9000 Strategy to Improve Performance of Manufacturing Company in East Java, Indonesia, European Journal of Business and management, Vol. 6., No. 29, pp. 125-136.

74)Kappelman, L.., Prybutok V. (1995): Empowerment, Motivation, Training and TQM Program Implementation Success, Total Quality Management, Industrial Management, Vol. 37, No. 3.

Paper sent to revision: 22.11.2015.

Paper ready for publication: 25.05.2016. 